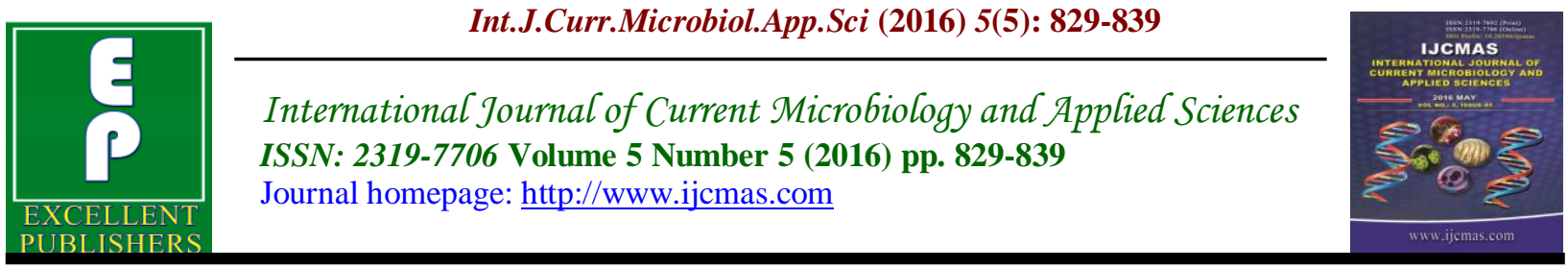

Original Research Article

http://dx.doi.org/10.20546/ijcmas.2016.505.085

\title{
Multiplex PCR test for the rapid detection of Mycobacterium tuberculosis in Pulmonary tuberculosis patients
}

\author{
S. H. Khater Enas ${ }^{1 *}$, Ahmed H. Sheren ${ }^{1}$ and Allam H. Amira ${ }^{2}$ \\ ${ }^{1}$ Department of Microbiology \& Immunology, Faculty of Medicine, Benha University, Egypt \\ ${ }^{2}$ Department of Chest Diseases, Faculty of Medicine, Benha University, Egypt \\ *Corresponding author
}

Keywords

Tuberculosis, Ziehl-neelsen, Multiplex PCR and mycobacteria growth indicator tube

Article Info

Accepted:

20 April 2016

Available Online:

10 May 2016
A B S T R A C T

Rapid, accurate and early diagnosis of tuberculosis is a major health concern especially in developing country like Egypt. This study aimed to evaluate Multiplex PCR (MPCR)using both MPB64 and IS6110 gene targets, and to compare it with conventional methods such as microscopy and mycobacteria growth indicator tube (MGIT) culture and also to compare with single target PCR IS6110 or MPB64 for rapid diagnosis of Mycobacterium tuberculosis (M. tuberculosis) from clinical samples. Sixty samples were processed for ZiehlNeelsen (ZN smear), MGIT culture and PCR for single target PCR IS 6110 target or MPB 64 gene target and MPCR (IS6110 \& MPB 64 gene target). Our study showed that out of 60 samples processed, 32 (53.3\%) were positive for AFB, whereas $42(70 \%)$ were positive for MGIT culture. PCR targeting IS6110 showed positive results $45(75 \%)$ as compared to PCR assay targeting MPB64 by which 40(66.7\%) samples showed positive results while the higher proportion of positive results were detected with MPCR was 49 (81.7\% ( samples. when clinical diagnosis was considered as the gold standard. AFB smear examination had a sensitivity of $53.3 \%$ and a specificity of $100 \%$. For MGIT culture test, sensitivity was $70 \%$ and specificity was $100 \%$. In comparison, single target PCR test was found to have a sensitivity of 75\% and 66,7\% for PCR 1 (IS 6110) and PCR 2 (MPB64) respectively And specificity was $90 \%$ while Multiplex PCR has much higher sensitivity $81.7 \%$ and specificity $92.3 \%$. Combined ZN smear \& MIGT culture showed $33(55 \%)$ positive smear and culture, 9(15\%) smear negative culture positive and $18(30 \%)$ smear negative culture negative samples. Of the 33 samples PCR positivity was found to be 33(100),30(90.9) and 28(84.8) with multiplex PCR, PCR 1 (IS 6110) and PCR 2 (MPB 64) respectively. In the 9 smear negative culture positive samples PCR positivity was observed as $8(88.9)$ in both PCR 1 (IS 6110) and multiplex PCR while PCR2 (MPB64) positivity 7)77.8\%. However the MPCR, PCR 1 (IS 6110) and PCR 2 (MPB 64) positivity was $8(44.4 \%), 7(38.9 \%)$ and $5(27.8 \%)$ in smear negative culture negative samples. This study reveals that multiplex TB-PCR, amplifying two targets specific for M. tuberculosis has higher specificity and sensitivity and can complement the tests in TB diagnosis and allow an initial therapeutic approach. 


\section{Introduction}

Tuberculosis (TB) remains a public health problem worldwide with a global mortality of 1.2 to 1.5 million in 2010 . The situation is further exacerbated with increasing incidence of multi-drug resistant (MDR) and extremely drug resistant (XDR) TB and emergence of HIV (WHO, 2011).

Though early diagnosis is mandatory in control of TB, especially for pulmonary TB as it is transmissible, it has remained enigmatic. Although, the conventional acid fast bacilli (AFB) microscopy has high positive predictive value for detection of causative agent (M. tuberculosis), it lacks sensitivity. Lowenstein-Jensen (L-J) culture test though considered as a gold standard is labour intensive and slow. Thus, detection of $M$. tuberculosis in clinical samples containing small numbers of the organism is still a major challenge (Kharibam, et al., 2016).

Polymerase chain reaction (PCR) based assays offer high sensitivity by amplification of small amount of DNA, and have been extensively evaluated for the detection of $M$. tuberculosis from clinical samples (Shinnick and Jonas, 1994). Many of the tests described are based on amplification of IS6110, an insertion element that is believed to be restricted to members of the $M$. tuberculosis complex (Chakravorty, et al., 2005). The presence of multiple copies of this element in the majority of $M$. tuberculosis strains undoubtedly enhances the sensitivity of PCR. However, the discovery of occasional $M$. tuberculosis strains lacking IS6110 (Van Soolingen et al., 1993) implies that relying only on IS6110based PCR is not advisable. initially, a PCR test was developed (Kadival, et al., 1993) targeting a house keeping gene of $M$. tuberculosis, for MPB64 gene, involved in phosphate transport (Harboe and Wiker, 1992).

Single gene target can result in false negative results while more reliable results are obtained by using more than one target gene for amplification. Multiplex PCR (MPCR) in which several target genes are amplified simultaneously is more sensitive and specific in diagnosis of Mycobacterium tuberculosis infection (MTB) (Kusum, et al., 2011).

The aim of the present study to evaluate multiplex PCR using both MPB64 and IS6110, and to compare it with conventional methods such as microscopy, and culture and also single target PCR either for IS6110 or MPB64 based PCR in rapid diagnosis of M. tuberculosis.

\section{Materials and Methods}

\section{Studied Subjects}

This was a cross-sectional, done in Microbiology and Immunology Departments, Benha University, Egypt from March 2015 to September 2015. Involved clinically suspected 60 cases of pulmonary tuberculosis Sputum samples were collected from subjects aged $>18$ years presenting to Chest Department and Outpatient Clinic of Benha University Hospital, Benha Chest hospital, Egypt, with fever, weight loss, cough, lymphadenopathy, abnormal physical examination or chest X-ray (CXR) suggestive of TB disease, ESR, positive history of contact/ family history or past history of tuberculosis, Positive Mantoux test, chronic TB (who tested positive after a Category II retreatment regimen), new sputum smear-positive TB (patients who did not convert to negative at 2 months of treatment) or default, relapse or treatment failure (previously treated cases) with a 
mean age of 34.7 years $( \pm 10.4$ standard deviation) and an equal gender distribution. In addition, 36 specimens from non-TB COPD and asthmatic patients were also included in the study as negative controls.

\section{Sputum Sample Collection}

Three successive morning sputum samples were collected in sterile containers.

\section{Decontamination and Concentration}

sputum was decontaminated with the sodium hydroxide-Nacetyl- L-cysteine (NaOH-NALC) method using BBL MycoPrep ${ }^{\mathrm{TM}} \quad$ Specimen Digestion/ Decontamination Kits (Becton Dickinson, Sporks, USA).Samples were then centrifuged at $3000 \times \mathrm{g}$ for $15 \mathrm{~min}$.

\section{Sputum Smear Microscopy (SSM)}

Two drops of $\mathrm{NaOH}-\mathrm{NALC}$ decontaminated sample pellet were used for smear microscopy (ZN staining), according to standard protocol. The grading of the AFB results was done in accordance with the WHO/International Union Against Tuberculosis and Lung Disease guidelines and scored as " 0 " for absence of AFB, scanty $1-9,1+, 2+$, or $3+$ (World Health Organization, 1998).

\section{MGIT Culture (Salman and Sabine, 2005)}

MGIT tue obtained from (Becton Dickinson, Sporks, USA) consists of liquid broth medium that is known to yield better recovery and faster growth of mycobacteria. The MGIT contains modified Middlebrook 7H9 broth base. This medium is terminally sterilized by autoclaving. An enrichment, MGIT OADC (Oleicacid, Albumin, Dextrose and Catalase). Addition of the
MGIT PANTA (Polymyxin B, Amphotericin B, Nalidixic acid,Trimethoprim and Azlocillin)

A lyophilized vial of BBL MGIT PANTA antibiotic mixture was reconstituted with 3 $\mathrm{ml}$ of sterile distilled water. The MGIT tube was labeled with specimen number, the cap was unscrewed and aseptically $0.5 \mathrm{ml}$ of MGIT OADC was added, then aseptically $0.1 \mathrm{ml}$ of reconstituted MGIT PANTA antibiotic mixture was added. For best results, the addition of OADC enrichment and PANTA antibiotic mixture was made just prior to specimen inoculation. $0.5 \mathrm{ml}$ of the concentrated specimen suspension was added the tube was tightly recapped and mixed well. Then the tube was incubated at $37{ }^{\circ} \mathrm{C}$. The tube was read daily starting on the second day of incubation using a UV lamp.

Preparation of interpretive negative and positive control tubes: Positive control tube was prepared by Empty broth from an uninoculated MGIT tube. $0.4 \%$ sodium sulfite solution was prepared $(0.4 \mathrm{~g}$ in 100 $\mathrm{ml}$ sterile distilled or deionized water) then 5 $\mathrm{ml}$ was added to the tube, the cap was replaced, tightened and the tube was allowed to stand for a minimum of $1 \mathrm{~h}$ at room temperature before use. Negative control tube: An unopened, uninoculated MGIT tube is used as a control.

Reading the tubes: tubes were removed from the incubator and placed on the UV light next to a positive control tube and negative control. Normal room light is preferred. MGIT tubes that showed bright fluorescence were visually located. Fluorescence was detected as a bright orange color in the bottom of the tube and also an orange reflection on the meniscus. The MGIT tubes were compared to positive control and negative control tubes. 
The presence of mycobacteria in the medium was confirmed by the presence of AFB after $\mathrm{ZN}$ staining and identification by biochemical tests (niacin accumulation and nitrate reduction).

\section{Biochemical Tests}

Niacin accumulation test (Young A et al., 1970)

Niacin TB test strips (Becton Dickinson, Sporks, USA) were used, these strips were dipped downward into the test (3-4 weeks old culture on which sterile distilled water was added) and negative control tubes (containing $0.5 \mathrm{ml}$ sterile DW) and left for 5-10 min. Positive test for niacin was indicated by the appearance of a yellow color in the test culture and no color in the control tube.

Nitrate Reduction Test (Virtanen et al., 1960)

A nitrate test strip (Becton Dickinson, Sparks, USA) was used. This strip was dipped into tube containing $0.5 \mathrm{ml}$ of DW, two spades (at least 50 colonies) from a 4 week old mycobacterial culture, then it was incubated at $37 \mathrm{oC}$ for $2 \mathrm{~h}$. Positive nitrate test was indicated by the appearance of a blue color in the top portion of the strip.

\section{DNA Extraction for Molecular Methods}

DNA was extracted from sputum by Thermo Scientific GeneJET Genomic DNA Purification Kit according to manufacturer's instructions and protocols. Eluted DNA was stored at $-20 \circ C$. To avoid contamination during DNA extraction and amplification, strict precautions were taken, including separate areas for DNA extraction, reagent preparation, amplification and product detection and regular meticulous cleaning of surface with $10 \%$ hypochlorite were also applied to maintain the standard molecular laboratory procedures

\section{DNA Amplification of Mycobacterium tuberculosis}

Amplification of $M$. tuberculosis dna using is6110 primer: (Sigma, bangalore, India)

First round of PCR was done on all extracted DNA samples. First PCR was carried out using the sequence for IS6110 gene (Tang et al., 2004). Primer 1: 5 -CCT GCG AGC GTA GGC GTC GG-3 Primer 2: 5 -CTC GTC CAG CGC CGC TTC GG-3 Each PCR reaction contained $1 \mathrm{x}$ buffer, $200 \mu$ M dNTPs, 1.5 U Taq Polymerase, 200 ng of each Primers and $5 \mu$ l of sample DNA per $50 \mu \mathrm{l}$ of reaction volume. DNA amplification was performed for 35 cycles following an initial denaturation at $940 \mathrm{C}$ for 5 min. in a thermal cycler (Biometra, Germany) by using following programme: denaturation at $940 \mathrm{C}$ for $1.5 \mathrm{~min}$., annealing at $700 \mathrm{C}$ and extension at $720 \mathrm{C}$ for $1.5 \mathrm{~min}$ with a final extension of $10 \mathrm{~min}$ at $720 \mathrm{C}$. The amplified product was stored at $40 \mathrm{C}$ till the detection by electrophoresis.

Amplification of $M$. tuberculosis DNA using MPB 64 primer (Sigma, Bangalore, India)

Second round of PCR was also done on all extracted samples by using primer for MPB 64 gene (Parekh et al., 2006): Primer 1: 5 TCC GCT GCC AGT CGT CTT CC-3 Primer 2: 5 - GTC CTC GCG AGT CTA GGC CA-3 Each reaction contained 1X buffer, $250 \mu \mathrm{M}$ dNTPs, $1.5 \quad \mathrm{U}$ Taq Polymerase $200 \mathrm{ng}$ of each of primer and 5 $\mu l$ of sample DNA per $50 \mu$ l of reaction. DNA amplification was performed for 30 cycle following an initial denaturation step 
at $940 \mathrm{C}$ for $5 \mathrm{~min}$ in the thermal cycler (Biometra, Germany) by using the following programme: denaturation at $940 \mathrm{C}$ for $2 \mathrm{~min}$, annealing at $50 \mathrm{OC}$ for $2 \mathrm{~min}$ and extension at $720 \mathrm{C}$ for $2 \mathrm{~min}$ with a final extension of $10 \mathrm{~min}$ at $72 \mathrm{0C}$. The amplified product was stored at $40 \mathrm{C}$ till the detection.

Detection Amplification of bacterial DNA was performed by using multiplex M.tuberculosis PCR.

Third round of MPCR was also done on all extracted samples by using primers (Sigma, Bangalore, India) for the IS6110 (IS1: 5'CCTGCGAGCGTAGGCGT-3' and IS2: 5'CTCGTCCA GCGCCGCTTCGG-3') and MPB64 (MPB1: 5'- ACC AGGGAGCG GTTCGCCTGG-3' and MPB2: 5'- GATCT GGGGGTCGTCGGAGCT-3') region of the M. tuberculosis complex; amplification conditions have been described earlier. (Sharma K. et al., 2006) The amplification protocol in the thermal cycler (Biometra, Germany) involved the following amplifications steps $\left(1\right.$ cycle at $94^{\circ} \mathrm{C}$ for 15 min; 40 cycles at $94^{\circ} \mathrm{C}$ for $30 \mathrm{~s}, 62^{\circ} \mathrm{C}$ for $1.30 \mathrm{~min}, 72^{\circ} \mathrm{C}$ for $1.30 \mathrm{~min} ; 1$ cycle at $72{ }^{\circ} \mathrm{C}$ for $10 \mathrm{~min}$ ).

\section{Detection of PCR Products}

Specific bands of 123 bp for IS6110 and 240 bp for MPB64 were visualized using fluorescence of ethidium bromide. The gel was transferred to the UV transilluminator. The (DNA bands) were observed by using ultraviolet light at wave length $312 \mathrm{~nm}$ in a dark room as showed in figures $1,2,3$. The sample was considered positive for MPCR if a specific band was seen in any or both of the two gene targets chosen. In every MPCR assay, results were compared with one positive (DNA of M.tuberculosis $\mathrm{H} 37 \mathrm{Rv}$ strain) and a negative (PCR-grade water) control. A 100-bp ladder was used as a molecular marker.

\section{Statistical Analysis}

The collected data were tabulated and analyzed using SPSS version 16 (SPSS Inc., Chicago, IL).Qualitative data were presented as frequencies and percentages.

\section{Results and Discussion}

Out of 60 samples processed, $32(53.3 \%)$ were positive for AFB, whereas $42(70 \%)$ were positive for MGIT culture. single gene target PCR assay 1 targeting IS6110 showed positive results $45(75 \%)$ as compared to PCR assay targeting MPB64 by which $40(66.7 \%)$ samples showed positive results while The higher proportion of positive results were detected with MPCR was 49 (81.7\% ( samples. when clinical diagnosis was considered as the gold standard. AFB smear examination had a sensitivity of $53.3 \%$ and a specificity of $100 \%$. For MGIT culture test, sensitivity was $70 \%$ and specificity was $100 \%$. In comparison, single target PCR test was found to have a sensitivity of $75 \%$ and $66,7 \%$ for PCR 1 (IS 6110) and PCR 2 (MPB64) respectively And specificity was $90 \%$ while MPCR has much higher sensitivity $81.7 \%$ and specificity $92.3 \%$ (Table 1).

Combined ZN smear \& MIGT culture showed $33(55 \%)$ positive smear and culture, $9(15 \%)$ smear negative culture positive and $18(30 \%)$ smear negative culture negative samples. Of the 33 samples PCR positivity was found to be 33(100),30(90.9) and 28(84.8) with multiplex PCR, PCR 1 (IS 6110) and PCR 2 (MPB 64) respectively. In the 9 smear negative culture positive samples PCR positivity was observed as 8(88.9) in both PCR 1 (IS 6110) and multiplex PCR while PCR2 (MPB64) positivity 7)77.8\%. However the MPCR, PCR 1 (IS 6110) and PCR 2 (MPB 64) positivity was 8(44.4\%), 
$7(38.9 \%)$ and $5(27.8 \%)$ in smear negative culture negative samples (Table 2).

PCR with its rapidity and higher sensitivity facilitates the early and accurate identification of the causative organism of tuberculosis (i.e. M. tuberculosis) and thus very helpful for treatment, prevention and control of this chronic infectious disease.PCR as molecular diagnostic had been used for many years for the detection of Mycobacterial DNA. However, PCR of mycobacterium DNA with one type of primer sometime may cause ambiguity in the detection of MTB-DNA and therefore, should be checked with other primers specific for Mycobacterium tuberculosis (Asthana and Madan, 2015).

Out of 60 samples processed, $32(53.3 \%)$ were positive for AFB, whereas 42(70\%) were positive for MGIT culture. single gene target PCR assay 1 targeting IS6110 showed positive results $45(75 \%)$ as compared to PCR assay targeting MPB64 by which 40(66.7\%) samples showed positive results while The higher proportion of positive results were detected with MPCR was 49 (81.7\%) (Gopinath and Singh, 2009) also reported that the multiplex PCR test showed the highest (77.24\%) detection rate, while $\mathrm{ZN}$ smear examination had the lowest $(20 \%)$ detection rate, which was bettered by L-J culture $(34.4 \%)$ and BACTECTM MGIT960 culture $(50.3 \%)$ methods (Asthana and Madan, 2015). Also reported that positive results were detected in70 (70\%) of samples PCR assay targeting M IS611, 48\% by PCR assay targeting MPB64 and $77 \%$ by MPCR. our results also was in agreement with Kidane et al., 2002 who reported PCR positivity results on such samples $83 \%$ using IS6110 systems.

In the present study AFB smear examination had a sensitivity of $53.3 \%$ and a specificity of $100 \%$. For MGIT culture test, sensitivity was $70 \%$ per cent and specificity was $100 \%$. In comparison, PCR test was found to have a much higher sensitivity of $81.7 \%$ and $75 \%$ for Multiplex PCR and PCR 1 (IS 6110) respectively. And specificity was $97.3 \%$ for Multiplex PCR and 90\% for PCR 1 (IS 6110), while PCR 2 (MPB64) has sensitivity $66.7 \%$ and specificity 90\%. M. tuberculosis detection by PCR was found to be significantly more sensitive and rapid compared to culture and microscopy with sensitivities ranging between $36 \%$ and $100 \%$ and specificities ranging between $85 \%$ and $100 \%$ using various PCR targets such as IS6110, MPB64, TRC4, GCRS, hup-B, Pab gene etc.) Bhanu, et al., 2005, Chakravorty, et al., 2005, Sankar S. et al., 2011, Katoch V. et al., 2004 and Jain, 2011). (Deshpande S. et al., 2007) stated that the IS6110 PCR assay was useful in terms of sensitivity $(82.4 \%)$ and specificity $(75.9 \%)$ as compared to culture results showing $68.6 \%$ sensitivity and $79.3 \%$ specificity Therefore, it has been found that IS6110 PCR is a good supportive method for rapid diagnosis of clinically diagnosed TBM. also Most reports of studies using IS6110-based detection have claimed sensitivities of over $75 \%$ and specificities approaching $100 \%$. Boondireke et al., 2007 stated the sensitivity (92.1\%) and specificity (98.2\%) of the multiplex PCR assay developed in their study for detecting $M$. tuberculosis have proved that the assay is reliable enough for diagnostic application.

In our study combined ZN smear \& MIGT culture showed $33(55 \%)$ positive smear and culture, $9(15 \%)$ smear negative culture positive and $18(30 \%)$ smear negative culture negative samples. Of the 33 samples PCR positivity was found to be 33(100), 30(90.9) and 28(84.8) with multiplex PCR, PCR 1 (IS 6110) and PCR 2 (MPB 64) respectively. Asthana A and Madan, 2015 
also reported that smear and culture positive group showed a sensitivity of $84.3 \%$ and 93.7\% for single target and multiplex PCR, respectively. Similar results also obtained by (Srivastava R. et al., 2006) who reported the sensitivity of 85 to $100 \%$. Though patients with positive smears are responsible for the maximum transmission of TB (Behr et al., 1999) demonstrated that smear-negative TB cases contribute much more to ongoing transmission than was previously believed. Thus early diagnosis of smear negative TB patients may prove to be a more pragmatic approach to control TB.

Table.1 Sensitivity and Specificity Observed with Smear Examination, Migt Culture and Multiplex PCR test.

\begin{tabular}{|c|c|c|c|c|c|}
\hline \multirow{2}{*}{ Method } & \multicolumn{5}{|c|}{ Sputum samples from PTB patients } \\
& $\begin{array}{c}\text { Positive } \\
\text { results }\end{array}$ & Sensitivity & Specificity & PPV & NPV \\
\hline AFB smear Microscopy & $32(53.3 \%)$ & $53.3 \%$ & $100 \%$ & $100 \%$ & $56.2 \%$ \\
\hline MIGT Culture & $42(70 \%)$ & $70 \%$ & $100 \%$ & $100 \%$ & $66.7 \%$ \\
\hline Multiplex PCR & $49(81.7 \%)$ & $81.7 \%$ & $92.3 \%$ & $94.2 \%$ & $76.6 \%$ \\
\hline PCR 1 (IS 6110) only & $45(75 \%)$ & $75 \%$ & $90 \%$ & $91.8 \%$ & $70.6 \%$ \\
\hline PCR 2 (MPB 64) only & $40(66.7 \%)$ & $66.7 \%$ & $90 \%$ & $88.2 \%$ & $54.5 \%$ \\
\hline
\end{tabular}

Table. 2 Comparison between Combined Culture \& Smear Results and PCR results

\begin{tabular}{|c|c|c|c|}
\hline $\begin{array}{c}\text { Culture \& smear } \\
\text { results }\end{array}$ & $\begin{array}{c}\text { PCR 1 (IS 6110) } \\
\text { only }\end{array}$ & $\begin{array}{c}\text { PCR 2 (MPB 64) } \\
\text { only }\end{array}$ & Multiplex PCR \\
\hline $\begin{array}{c}\text { Smear positive } \\
\text { Culture positive } \\
\text { N=33 }\end{array}$ & $30(90.9)$ & $28(84.8)$ & $33(100)$ \\
\hline $\begin{array}{c}\text { Smear negative } \\
\text { Culture positive } \\
\text { N=9 }\end{array}$ & $8(88.9)$ & $7(77.8 \%)$ & $8(88.9)$ \\
\hline $\begin{array}{c}\text { Smear negative } \\
\text { Culture negative } \\
\mathbf{N = 1 8}\end{array}$ & $7(38.9 \%)$ & $5(27.8 \%)$ & $8(44.4 \%)$ \\
\hline $\begin{array}{c}\text { Control } \\
\mathbf{N = 3 6}\end{array}$ & $4(11.1 \%)$ & $4(11.1 \%)$ & $3(8.3 \%)$ \\
\hline
\end{tabular}


Fig.1 IS6110 Gene Targeted In-house PCR for Detection of Mycobacterium tuberculosis

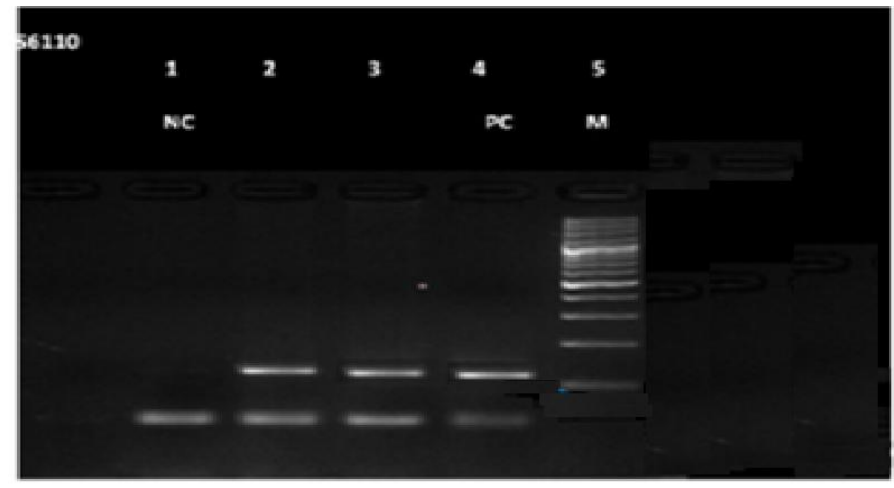

Lanes 1-5. Lanes-1 represents the negative control (nuclease free water), Lane-2 and 3 represent clinical pulmonary samples, Lanes-4 was positive control (Mycobacterium tuberculosis culture H37Rv). Lane-5 was $100 \mathrm{bp}$ marker. The presence of a $123 \mathrm{bp}$ amplicon in the lanes 2-4 indicated the presence of the target.

Fig.2 MPB64 Gene Targeted PCR for Detection of Mycobacterium tuberculosis
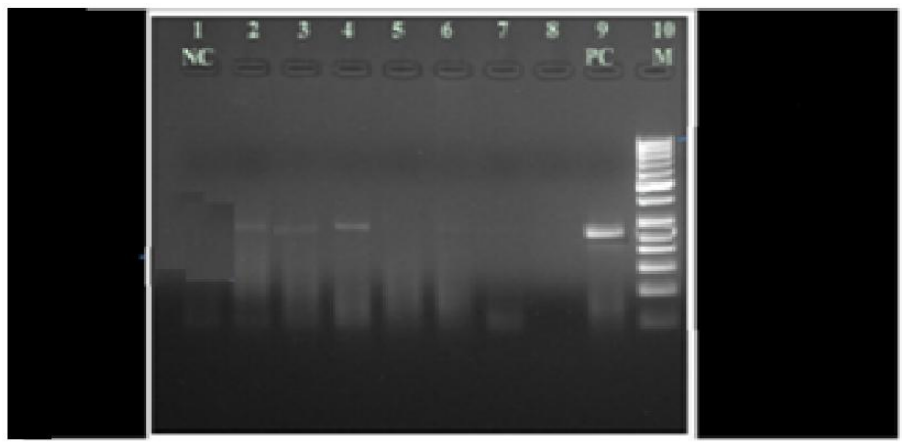

Lanes 1-10. Lanes-1 represents the negative control (nuclease free water), lane-2 to 8 represents clinical pulmonary samples, Lanes-9 was positive control H37Rv (Mycobacterium tuberculosis culture). Lane-10 was 50bp marker. The presence of a 240bp. amplicon in the lanes 2 to 4, 9 indicated the presence of the target.

Fig.3 A Multiplex PCR Test for the Detection of Mycobacterium tuberculosis

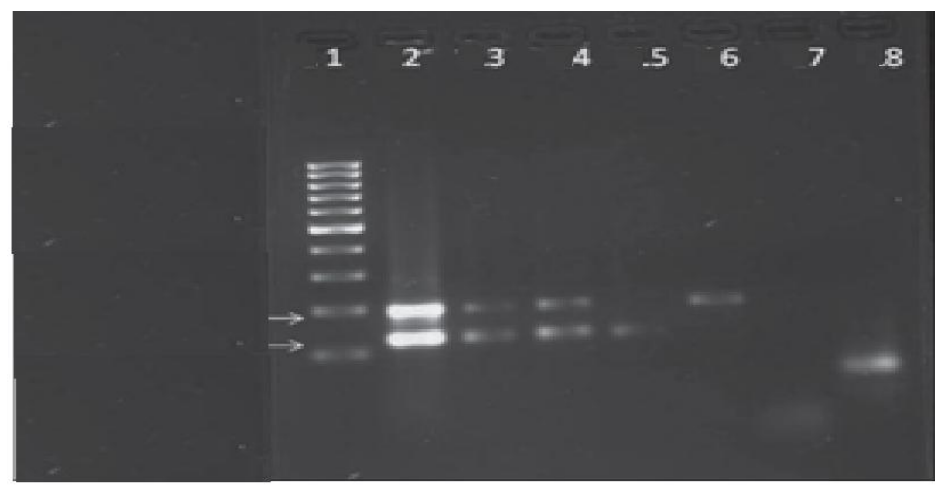

LI: 100-bp molecular marker, L2: Positive control, L3,4: Patient sample DNA positive for both the bands, L5: Clinical sample positive for IS6110, L6: Clinical sample positive for MPB64 band, L7: Negative control, L8: Negative patient sample. The presence of a $123 \mathrm{bp}$ a $240 \mathrm{bp}$ amplicon in the lanes $2-4$ indicated the presence of the target. 
In the present study of the 9 smear negative culture positive samples PCR positivity was observed as 8(88.9) in both PCR 1 (IS 6110) and multiplex PCR while PCR2 (MPB64) positivity 7) $77.8 \%$. PCR positivity was observed as 8(88.9) in both PCR 1 (IS 6110) and multiplex PCR while PCR2 (MPB64) positivity 7) $77.8 \%$ (in smear negative culture positive. This result was comparable with Negi S et al., 2006 who reported sensitivity of $73.6 \%$ with multiplex PCR in smear negative culture positive which is higher than the majority of the studies reporting it at around $60 \%$ or even less by Sarmiento O. et al., 2003. However, the present study shows that the protocol for DNA extraction and PCR used in our laboratory was highly satisfactory and nonspecific inhibition was seen only in 1 out of 9 mycobacteriologically confirmed specimens.

In the present study however the MPCR, PCR 1 (IS 6110) and PCR 2 (MPB 64) positivity was $8(44.4 \%), \quad 7(38.9 \%)$ and $5(27.8 \%)$ in the18 smear negative culture negative sample which probably could be tuberculosis in patients on anti-tuberculosis treatment shedding non-cultivable bacteria. eight of these 18 , were positive by multiplex PCR. These 8 smear negative culture negative samples were stained with flourescin diacetate- ethidium bromide and showed green stained bacilli method indicating presence of live bacilli which were not detected by MGIT culture test (Dezemon Z. et al., 2003.). PCR-positive results without bacteriological confirmation of the specimen are often doubted as false positive, but these apprehensions are not often true. In some cases, this may be the only evidence of infection. Nevertheless, care should be taken while interpreting the PCR results if considered as sole evidence. The criteria of diagnosis of tuberculosis in smear and culture negative pulmonary tuberculosis suspect's may constitute and the epidemiological, clinical, radiological, tuberculin testing, and response to treatment, along with $M$. tuberculosis PCR. (Katoch et al., 2004)

In conclusion, this study reveals that multiplex TB-PCR, amplifying two targets specific for $M$. tuberculosis has higher specificity and sensitivity and can complement the tests in TB diagnosis and allow an initial therapeutic approach. and also significant multiplex TB-PCR has utility in the early diagnosis (by decreasing time duration) of pulmonary smear negatives tuberculosis which is not diagnosed by conventional test or low detection rate by $\mathrm{ZN}$ smear and mycoacterial culture, more work is needed to evaluate the using of multiplex PCR for diagnosing tuberculosis in pulmonary cases in Egypt.

\section{References}

Asthana K. A. and Madan M. :Study of Target gene IS 6110 and MPB 64 in Diagnosis of Pulmonary Tuberculosis Int. J. Curr. Microbiol. App. Sci 2015;4(8): 856-863

Behr MA, Warren SA, Salamon H, Hopewell PC, Ponce de Leon A, Daley CL, et al.,. Transmission of Mycobacterium tuberculosis from patients smear-negative for acid-fast bacilli. Lancet. 1999;353:444-9.

Bhanu N. V., Singh U. B., Chakravorty M., Suresh N., Arora J., Rana T., Takkar D. and Seth P. Improved diagnostic value of PCR in the diagnosis of female genital tuberculosis leading to infertility. J Med Microbiol, 54, 927931, 2005.

Boondireke S., Mungthin M., Tan-ariya, P., Boonyongsunchai P., Naaglor T., Anan Wattanathum, Sompong Treewatchareekorn,4 and Saovanee 
L.:Evaluation of Sensitivity of Multiplex PCR for Detection of Mycobacterium tuberculosis and Pneumocystis jirovecii in Clinical Samples J Clin Microbiol. 2010 Sep; 48(9): 3165-3168.

Chakravorty S., Dudeja M., Hanif M., Tyagi J.S.: Novel multipurpose methodology for detection of mycobacteria in pulmonary and extrapulmonary specimens by smear microscopy, culture, and PCR. J Clin Microbiol 2005; 43 : 2697-702.

Chakravorty S., Sen M. K. and Tyagi J. S.. Diagnosis of pulmonary tuberculosis by smear, culture, and PCR using universal sample processing technology. J Clin Microbiol, 43, 4357-4362, 2005.

Deshpande P. S., Kashyap R. S., Ramteke S. S, Nagdev K. J, Purohit H. J, and Hatim F Daginawala: Evaluation of the IS6110 PCR assay for the rapid diagnosis of tuberculous meningitis. Cerebrospinal Fluid Res. 2007; 4: 10.

Dezemon Z., Muvunyi C.M. and Jacob O. staining techniques for detection of acid fast bacilli: what hope does fluorescein-diacetate (FDA) vitality staining technique represent for the monitoring of tuberculosis treatment in resource limited setting, Trends in Bacteriology; 2014; 1:1-6 DOI : http://dx.doi.org/10.7243/2057-4711$1-1$.

Gopinath K. and Singh S.: simultaneous detection and differentiation of Mycobacterium tuberculosis, Mycobacterium avium complexes and other Mycobacterial species directly from clinical specimens journal of applied microiology 2009; 107:425435.

Harboe M. and Wiker H.G. The $38 \mathrm{kDa}$ protein of Mycobacterium tuberculosis: A review. J Infect Dis 1992; 166 : 874-84.

Jain A. Extra pulmonary tuberculosis: A diagnostic dilemma. Ind $\mathbf{J}$ ClinBiochem, 26, 269-273, 2011.

Kadival G. V., D'Souza C.D., Kulkarni S.P. and Samuel A.M.: A highly specific polymerase chain reaction test for detection of Mycobacterium tuberculosis. Indian J Tuberc 1996; 42: 151-4.

Katoch V. M. Newer diagnostic techniques for tuberculosis. Ind J Med Res, 120, 418-428, 2004.

Kharibam S., Farooq U. and Nudrat S.: Molecular Detection of Mycobacterium tuberculosis Complex from Clinical Sputum Samples in Patients Attending Tertiary Care Centre in Uttar Pradesh Province of India Acta Medica International 2016; 3 (1) 102-106.

Kidane D, Olobo JO, Habte A, Negesse Y, Aseffa A, Abate G, Yassin MA, Bereda $\mathrm{K}$ and Harboe $\mathrm{M}$ Identification of the causative organism of tuberculosis in Ethiopia by PCR. J Clin Microbiol 2002;40: 4230-4234.

Kusum S, Aman S, Pallab R, Kumar SS, Manish M, Sudesh P, et al.,. Multiplex PCR for rapid diagnosis of tuberculous meningitis. J Neurol. 2011;258:1781-7

Negi SS, Anand R, Basir SF, Pasha ST, Gupta S, Khare S, et al.,. Protein antigen $b(\mathrm{Pab})$ based PCR test in diagnosis of pulmonary \& extrapulmonary tuberculosis. Indian J Med Res. 2006;124:81-8.

Parekh, K.M., Inamdar, V., Jog, A., Kar, A.. A comparative study of the diagnosis of pulmonary tuberculosis using conventional tool and polymerase chain reaction. Ind. J.Tuberc. 2006; 53:69-76 
Salman H. Siddiq and Sabine Ru" schGerdes. Section I: principle of procedure, in: M G I TTM Procedure Manual, 2006, pp. 10-11.

Sandhu, G. S., B. C. Kline, L. Stockman, G. D. Roberts, and M. E. Lewis. IS6110 based molecular detection of Mycobacterium tuberculosis. U.S. patent 1998;5,731,150.

Sankar S., Kuppanan S., Balakrishnan B. and Nandagopal B.. Analysis of sequence diversity among IS6110 sequence of Mycobacterium tuberculosis: possible implications for PCR based detection. Bioinformation, 6, 283-5, 2011.

Sarmiento OL, Weigle KA, Alexander J, Weber DJ, Miller WC. Assessment by meta-analysis of PCR for diagnosis of smear-negative pulmonary tuberculosis. J Clin Microbiol. 2003;41:3233-40.

Sharma K. Sharma A. Sharma S K. Sen R K. Dhillon MS Sharma M. Does multiplex PCR increase the diagnostic procedure in osteoarticular Tuberculosis int orthop.2012;36:2559.

Shinnick T.M.and Jonas V.: Molecular approaches to the diagnosis of tuberculosis. In: Bloom BR, editor. Tuberculosis: Pathogenesis, protection and control. Washington DC: American Society for Microbiology Press; 1994. p. 517-30.

Srivastava R, Kumar D, Waskar MN, Sharma M, Katoch VM, Srivastava
BS. Identification of a repetitive sequence belonging to a PPE gene of Mycobacterium tuberculosis and its use in diagnosis of tuberculosis. J Med Microbiol. 2006;55:1071-7

Tang, Y.W., Meng, S., Li, H., Stratton,C.W., Koyamatsu, T., Zheng, X. 2004. PCR Enhances Acid-Fast Bacillus StainBased Rapid Detection of Mycobacterium tuberculosis. J. Clin. Microbiol.;42(4):1849-50.

Van Soolingen D., DeHaas P., Hermans P., Groenen P. and van Embden J.: Comparison of various repetitive DNA elements as genetic markers of strain differentiation of epidemiology of Mycobacterium tuberculosis. J Clin Microbiol 1993; 31 : 1887-95.

Virtanen S., A study of nitrate reduction by mycobacteria, Acta.Tuberc. Scand. Suppl. 48 (1960) 1-119.

World Health Organization. Global tuberculosis control: report 16 . Geneva: WHO; 2011

World Health Organization: Laboratory Services in Tuberculosis Control, Part 2: Microscopy Publication Number World Health Organization, Geneva, Switzerland (1998)

Young, A. Maslansky, M. Lafar, wDevelopment of a paper strip test for detection of niacin produced by mycobacteria, Appl. Microbiol. 10 (1970) 939-945.

\section{How to cite this article:}

Khater Enas, S. H., Ahmed H. Sheren and Allam H. Amira. 2016. Multiplex PCR test for the rapid detection of Mycobacterium tuberculosis in Pulmonary tuberculosis patients. Int.J.Curr.Microbiol.App.Sci.5(5): 829-839. doi: http://dx.doi.org/10.20546/ijcmas.2016.505.085 